\title{
Keratinophilic and Thermophilic Fungi from Animal Manures and Floor Dust in the Vicinity of Ayatt, Giza, Egypt.
}

\author{
A. El-Gindy, O. El-Mahdy ${ }^{*}$, Z. Ibrahim and H. Aziz \\ Dephtment of Biological and Geological Sciences, Faculty of \\ Education, 11341 Heliopolis, Ain Shams Univ. Cairo, Egypt.
}

\begin{abstract}
A ORTY SEVEN samples of animal manures and thirty eight I samples of floor dust were randomly collected from the vicinity of Ayatt City during September - November 2013. Keratinophilic and thermophilic fungi were isolated. A total of 26 sp belonging to 15 genera and $23 \mathrm{sp}$ belonging to 17 genera of keratinophilic and thermophilic fungi were identified, respectively. Out of 76 encounters of animal manures Thamnostylum piriforme was the most frequent $(10.52 \%)$ followed by Aspergillus brasiliensis = Chrysosporium keratinophilum (7.89\%) each. 78 encounters were isolated from floor dust. The most frequent was Arachniotus dankaliensis (10.25\%) followed by Candida albicans (7.69\%). 76 isolates of thermophilic fungi were isolated from animal manure. Aspergillus fumigatus is the most frequent $(9.21 \%)$ followed by Aspergillus flavus var. columnaris (7.89\%). 75 isolates were identified from floor dust. Again, Aspergillus fumigatus is the most frequent $(9.33 \%)$. Aspergillus brasiliensis $=A$. carneus $=$ A. flavus var. columnaris $=$ Rasamsonia byssochlamydoides $=$ Chrysosporium zonatum $(6.66 \%)$ each comes second. The clinical importance of certain fungi was discussed.
\end{abstract}

Keywords: Fungi, Animal manure, Floor dust, Egypt.

Keratinofers are opportunisitic and/ or pathogenic fungi infecting man and animals. Keratinolytic fungi are able to attack and decompose keratin, whereas keratinophilic ones accompany them utilizing the products of keratin degradation. Keratinofers have been divided into three categories according to their natural habitats: anthropohilic that infects humans, zoophilic which infects animals and geophilic when soil is the natural habitat. Presence of humans and animals in the environment increases the incidence of keratinofers. Biology, physiology and ecology of these fungi have been invistigated throughout the world (Abdel-Fatlah et al., 1982; Garg et al., 1985; Abdel-Hafez et al., 1990; Kunert, 2000; Katiyar \& Kushwaha, 2002; Bohacz and Kornittowicz-Kowalska, 2012; Sharma \& Ghoudhary, 2014; Bisen \& Tiwari, 2015 and Khan \& Bhadauria, 2015).

Heat- tolerant fungi can be classified as thermophiles or thermotolerant, depending on their cardinal growth temperatures. The definition of Cooney \&

*Correspondance Author. Abc200426@ yahoo.com. 
Emerson (1964) consider thermophilic fungi to be those with maximum growth temperature of $50{ }^{\circ} \mathrm{C}$ or above and minimum growth temperature of $20{ }^{\circ} \mathrm{C}$ or above. Thermotolerant fungi are those that grow at maximum temperature up to $50{ }^{\circ} \mathrm{C}$ with a minimum temperature below $20{ }^{\circ} \mathrm{C}$. Although this classification is quite practical, it is not applicable to all fungi. For example Aspergillus fumigatus is able to grow at temperature above $50{ }^{\circ} \mathrm{C}$ and below $20{ }^{\circ} \mathrm{C}$. Alternatively, Maheshwari et al., (2000) proposed that thermophilic fungi are those with an optimum growth temperature of $45{ }^{\circ} \mathrm{C}$ or above. Thermophilic fungi play an important role in composting in soil, some are opportunistic pathogens and others are allergenic (Sirinivasan et al., 2005). Comprehensive reviews are available: (Cooney and Emerson, 1964; Maheshwari et al., 1987 \& 2000; Mouchaea, 1997 \& 2007, Salar and Aneja, 2007 and Singh and Satyanarayana, 2014).

The objective of this study is the isolation and identification of both keratinophilic and thermophilic fungi from animal manures and floor dust in the vicinity of Ayatt, Giza, Egypt.

\section{Material and Methods}

\section{Collection of Soil Samples}

A total of 47 and 38 samples of animal manure and floor dust was randomly collected during September - December 2013 in sterile plastic bags and brought to laboratory and stored at $8{ }^{\circ} \mathrm{C}$.

\section{Isolation of Keratinophilic Fungi}

Keratinophilic fungi were isolated by the hair - baiting technique (Vanbreseghem, 1952). Twenty g. from each soil samples were placed in $90 \mathrm{~mm}$ sterile Petri plate in five replicates. A sterile defatted human hair fragments (1-2 $\mathrm{cm})$ were scattered on the surface of soil. The plates were moistened with antibiotic solution containing $50 \mathrm{mg} \mathrm{L}^{-1}$ chloramphenicol and $500 \mathrm{mg} \mathrm{L}^{-1}$ cyclohoximide. Petri plates were sealed with cellophane tapes and incubated at 28 ${ }^{\circ} \mathrm{C}$ for 4-6 weeks and moistened periodically with sterile water. If fungal growth was observed, the baits were transferred to plates containing Sabouraud Dextrose Agar (SDA) supplemented with chloramphenicol and cycloheximides as previously mentioned and inoculated at $28{ }^{\circ} \mathrm{C}$. Fresh developed colonies were isolated, purified, examined and identified.

\section{Isolation of Thermophilic Fungi}

Ten mg of animal manure or floor dust were transferred asceptically to $90 \mathrm{~mm}$ Petri plates using sterile spatula. Twenty $\mathrm{ml}$ of semi- liquid yeast-glucose agar medium (Cooney and Eerson, 1964) were poured in each plate and hand swirled and left to solidify. Plates were then incubated at $45{ }^{\circ} \mathrm{C}$ for $4-6$ days. The developed colonies were isolated, purified, examined and identified.

\section{Identification of Fungi}

Pure culture was maintained on the appropriate media and identified according to the following discriptive manuals: (Cooney and Emerson, 1964; Frey et al., 1979; Domsch et al., 1980; van Oorschot, 1980; Moubasher, 1993; de Egypt. J. Bot., 56, No. 3 (2016) 
Hoog and Guarro, 1995; Mouchaea, 1997; Latge, 2003; Ellis et al., 2007 and Campell et al., 2013). Identification of certain isolated was confirmed by the Authorities of AUMC (Assuit, Egypt, 71516) to whom the authors are greatly indebted. Number of fungus encounters and frequency for each species were calculated and represented in tables. Current names of fungi were used.

\section{Results and Discussion}

A total of 18 species belonging to 11 genera and 22 species belonging to 14 genera of keratinophilic fungi was isolated from animal manures and floor dust samples, respectively (Table 1). Out of 76 encounters of animal manure, Thamnostylum piriforme comes first ( 8 encounters and $10.52 \%$ frequency). In the second order comes Aspergillus brasiliensis = Chrysosporium keratinophilum $(6$ and $7.89 \%)$. The order of rest of fungi in descending manner is found to be: Mucor circinilloides $=M$. hiemalis $=$ Aspergillus flavus $=$ A. fumigatus $=$ Exserohilum rostratum $=$ Fusarium solani (5), $6.57 \%$ each $>$ Aspergillus ustus $=$ Phoma glomerata (4), 5.26 each $>$ Rhizopus stolonifer $=$ Aspergillus sydowii $=$ Penicillium duclauxii $=$ Trichophyton terrestre (3), 3.94\%> Cunninghamella echinulata $=$ Mucor racemosus $=$ Penicillium purpurogenum (2), 2.63\% each, respectively.

Concerning floor dust Arachniotus dankaliensis comes first (8), $10.25 \%$ followed by Candida albicans (6), 7.69\%. In descending order the rest of fungi is found to be Aspergillus brasiliensis $=$ A. fumigatus $=$ A . parasiticus $=$ Phoma glomerata $=$ Scopulariopsis brevicaulis (5), 6.41> Circinella muscae $=$ Aspergillus flavus (4), 5.13\%> Absidia corymbifera $=$ Chrysosporium indicum $=$ C. tropicum $=$ Fusarium solani $=$ Penicillium duclauxii $=$ P. purpurogenum (3), $3.85 \%>$ Cunninghamella echinulata $=$ Mucor hiemalis $=$ M. racemocus $=$ Rhizopus stolonifer $=$ Aspergillus ustus $=$ Chrysosporium keratinophillum (2), $2.56 \%>$ Trichophyton terrestre (1), $1.28 \%$ each respectively.

Keratinophilic fungi were isolated from animal sheds and floor dust throughout the world (Maghraby et al., 2008; Singh et al., 2009; Al-Humiany, 2010; Jain and Sharma, 2012; Deshmukh and Verekar, 2012; Kacinova et al., 2013; Sarkar et al., 2014 and Deshmukh and Verekar, 2014). Keratinophilic fungi are associated with human and/ or animal activities (Table 2)

Concerning thermophilic fungi 76 encounters belonging to $20 \mathrm{spp}$ from 15 genera and 75 encounters belonging to $20 \mathrm{spp}$ from 14 genera were isolated from animal manure and floor dust, respectively. Aspergillus fumigatus was the most frequent in animal manure (7 encounters and 9.21\% frequency, followed by Aspergillus flavus var columnaris (6) 7.89\%> Absidia corymbifera $=$ Rhizomucor pusillus $=$ Aspergillus brasiliensis $=$ Chrysosporium zonatum (5) $6.57 \%$ each $>$ Chaetomium thermophilum $=$ Myceliophthora thermophila $=$ Papulospora thermophila $=$ Scytalidium thermophilum (4) $5.56 \%$ each $>$ Rhizopus rhizopodoformis $=$ Aspergillus terreus $=$ Emericella nidulans $=$ Malbranchea cinnamomea $=$ Thermoascus aurantiacus $=$ Thermomyces lanuginosus (3) $3.94 \%$ each> Rhizomucor miehei =Rasamsonia emersoni $=$ Remersonia thermophila (2) $2.63 \%$ each respectively. 
TABLE 1. Fungal species encounters (ENC) and percentage frequency $(\%)$ of keratinophilic fungi isolated from animal manures (AM) and floor dust (FD).

\begin{tabular}{|c|c|c|c|c|}
\hline \multirow[t]{2}{*}{ Fungal species } & \multicolumn{2}{|c|}{$\mathbf{A} \mathbf{M}$} & \multicolumn{2}{|c|}{ F D } \\
\hline & ENC & $\%$ & ENC & $\%$ \\
\hline Absidia corymbifera (Cohn) Saccardo \& Totter & 0 & 0 & 3 & 3.85 \\
\hline Circinela muscae (Sorokin) Berlse \& Toni & 0 & 0 & 4 & 5.13 \\
\hline Cunninghamella echinulata (Thaxter) Thaxter & 2 & 2.63 & 2 & 2.56 \\
\hline Mucor circinilloides van Teighem & 5 & 6.57 & 0 & 0 \\
\hline Mucor hiemalis Wehmer & 5 & 6.57 & 2 & 2.56 \\
\hline Mucor racemosus Fresenius & 2 & 2.63 & 2 & 2.56 \\
\hline Rhizopus stolonifer (Erhenberg) Vuillemin & 3 & 3.94 & 2 & 2.56 \\
\hline $\begin{array}{l}\text { Thamnostylum piriforme (Bainier) von Arx \& } \\
\text { Upahyay }\end{array}$ & 8 & 10.52 & 0 & 0 \\
\hline Aspergillus brasiliensis Varga, Frisvad \& Samson & 6 & 7.89 & 5 & 6.41 \\
\hline Aspergillus flavus (Link) & 5 & 6.57 & 4 & 5.13 \\
\hline Aspergillus fumigatus Fresenius & 5 & 6.57 & 5 & 6.41 \\
\hline Aspergillus parasiticus Speare & 0 & 0 & 5 & 6.41 \\
\hline $\begin{array}{l}\text { Aspergillus sydowii (Bainer \& Sartory)Thome \& } \\
\text { Church }\end{array}$ & 3 & 3.94 & 0 & 0 \\
\hline Aspergillus ustus (Bainier) Thom \& Church & 4 & 5.26 & 2 & 2.56 \\
\hline Arachniotus dankalensis (Castellani) va Beyma & 0 & 0 & 8 & 10.25 \\
\hline Candida albicans (Robin) Berkhout & 0 & 0 & 6 & 7.69 \\
\hline $\begin{array}{l}\text { Chrysosporium indicum (Randhawa \& Sandha) } \\
\text { Garg }\end{array}$ & 0 & 0 & 3 & 3.85 \\
\hline Chrysosporium kertinophilum Frey (Carmichael) & 6 & 7.89 & 2 & 2.56 \\
\hline Chrysosporium tropicum (Carmichael) & 0 & 0 & 2 & 3.85 \\
\hline Exserohilum rostratum (Drechsler) Leonard \& Sugg & 5 & 6.57 & 0 & 0 \\
\hline Fusarium solani (Martin) Saccardo & 5 & 6.57 & 3 & 3.85 \\
\hline Penicillium duclauxii Delacroxi & 3 & 3.94 & 3 & 3.85 \\
\hline Penicillium purpurogenum Stoll & 2 & 2.63 & 3 & 3.85 \\
\hline $\begin{array}{l}\text { Phoma glomerata (Corda) Wollenweber \& } \\
\text { Hochapfel }\end{array}$ & 4 & 5.26 & 5 & 6.41 \\
\hline Scopulariopsis brevecaulis (Saccardo) Bainier & 0 & 0 & 5 & 6.41 \\
\hline Trichophyton terrestre Durie \& Frey & 3 & 3.94 & 1 & 1.28 \\
\hline No. of Total Encounters & & & 78 & \\
\hline No. of Species & & & 22 & \\
\hline No. of Genera & & & 14 & \\
\hline
\end{tabular}


KERATINOPHILIC AND THERMOPHILIC FUNGI FROM ANIMAL ...

TABLE 2. Fungal species encounters(ENC) and percentage frequency $(\%)$ of thermophilic fungi isolated from animal manures (AM) and floor dust (FD).

\begin{tabular}{|c|c|c|c|c|}
\hline \multirow[t]{2}{*}{ Fungal species } & \multicolumn{2}{|c|}{$\mathbf{A} \mathbf{M}$} & \multicolumn{2}{|c|}{ F D } \\
\hline & ENC & $\%$ & ENC & $\%$ \\
\hline Absidia corymbifera (Cohn) Saccardo \& Trotte & 5 & 6.57 & 3 & 4.00 \\
\hline $\begin{array}{l}\text { Rhizomucor miehei (Cooney \& Emerson) } \\
\text { Schipper }\end{array}$ & 2 & 2.63 & 2 & 2.66 \\
\hline Rhizomucor pusillus (Lindt) Shipper & 5 & 6.57 & 3 & 4.00 \\
\hline Rhizopus rhizopodoformis (Cohn) Zopf & 3 & 3.94 & 2 & 2.66 \\
\hline $\begin{array}{l}\text { Aspergillus brasiliensis Varga, Frisvad \& } \\
\text { Samson }\end{array}$ & 5 & 6.57 & 5 & 6.66 \\
\hline Aspergillus carneus Blockwitz & 3 & 3.94 & 5 & 6.66 \\
\hline $\begin{array}{l}\text { Aspergillus flavus var Columnaris Raper \& } \\
\text { Fennel }\end{array}$ & 6 & 7.89 & 5 & 6.66 \\
\hline Aspergillus fumigatus Fresenius & 7 & 9.21 & 7 & 9.33 \\
\hline Aspergillus terreus Thom & 3 & 3.94 & 4 & 5.33 \\
\hline Chaetomium thermophilum La Touche & 4 & 5.56 & 2 & 2.66 \\
\hline Chrysosporium zonatum Al-Musallam \& Tan & 5 & 6.57 & 5 & 6.66 \\
\hline Emericella nidulans (Eidam) Vuillemin & 3 & 3.94 & 3 & 4.00 \\
\hline Fennellia nivea (Wiley \& Simmons) Samson & 0 & 0 & 3 & 4.00 \\
\hline $\begin{array}{l}\text { Malbranchea cinamomea (Libert) van Oovshot } \\
\& \text { de Hoog }\end{array}$ & 3 & 3.94 & 4 & 5.33 \\
\hline $\begin{array}{l}\text { Myceliophthora thermophila (Apinis) van } \\
\text { Oorshot }\end{array}$ & 4 & 5.56 & 3 & 4.00 \\
\hline Papulospora thermophila Fergus & 4 & 5.56 & 0 & 0 \\
\hline Paceliomyces variotii (Thom) Samson & 0 & 0 & 4 & 5.33 \\
\hline $\begin{array}{l}\text { Rasamsonia byssochlamydoides } \\
\text { (Stolk\&Samson)Houbraken\&Frisvad }\end{array}$ & 0 & 0 & 5 & 6.66 \\
\hline $\begin{array}{l}\text { Rasamsonia emersonii (Stolk) Houbraken \& } \\
\text { Frisvad }\end{array}$ & 2 & 2.63 & 0 & 0 \\
\hline $\begin{array}{l}\text { Remersonia thermophila (Fergus) Seifert \& } \\
\text { Samson }\end{array}$ & 2 & 2.63 & 0 & 0 \\
\hline $\begin{array}{l}\text { Scytalidium thermophilium (Cooney \& } \\
\text { Emerson) Austwick }\end{array}$ & 4 & 5.56 & 4 & 5.33 \\
\hline Thermoascus aurantiacus Miehe & 3 & 3.94 & 4 & 5.33 \\
\hline Thermomyces lanuginosus Tsiklinsky & 3 & 3.99 & 2 & 2.66 \\
\hline No. of Total Encounters & & & & \\
\hline No. of Species & & & & \\
\hline No. of Genera & & & & \\
\hline
\end{tabular}

Egypt. J. Bot., 56, No. 3 (2016) 
In floor dust Aspergillus fumigatus was the most frequent (7) $9.33 \%$ followed by Aspergillus brasiliensis $=$ A. carneus $=$ A. flavus var columnaris = Rasamsonia byssochlamydoides = Chrysosporium zonatum (5) $6.66 \%$ each > Aspergillus terreus $=$ Malbranchea cinamomea $=$ Paceliomyces variotii $=$ Scytalidium thermophilum $=$ Thermoascus auratiacus (4) $5.33 \%$ each $>$ Absidia corymbifera $=$ Rhizomucor pusillus $=$ Emericella nidulans $=$ Fennillia nivea $=$ Myceliophthora thermophila (3) $4.0 \%$ each $>$ Rhizomucor miehei $=$ Rhizopus rhizopodoformis $=$ Chaetomium thermophilum = Thermomyces lanuginosus (2) $2.66 \%$ each respectively. Thermophilic and thermotolerant fungi play an important role in animal manure compositing. Mature (cured ) animal manure is a good substrate as organic fertilizer. Application of immature animal manure (in mesophilic or thermogenic phases) is not saved from the hygenic point of view. Thermophilic fungi with clinical importance have been reported (El-Gindy et al., 2002; Alhumiany, 2010; Rajavanaram et al., 2010; Sreelatha et al., 2013 and Singh and Satyanarayana, 2014).

Yang et al., (2016) reviewed soil fungi implicated in animal and human pathogenesis.

Frequent occurrence of Thamnostylum piriforme has been reported earlier (Benny and Benjamin, 1975). In Egypt, T. piriforme was reported from buffalocows that failed to conceive (Morsy, 2007).

Aspergillus brasiliensis is newly described species (Varga et al., 2007), which was in part created by the transfer of several existing $A$. niger strains to the new sp. A. brasiliensis is upiquitous soil fungus. Up to now A. brasiliensis has not been implicated in human diseases.

Chrysosporium spp is frequent keratinophilic soil fungi. Localised and dissiminated infections in healthy and immunocsmpromised individuals due to Chrysosporium keratinophilum, $C$. zonatum (both are thermotolerant) and $C$. tropicum may occur. Primary cutaneous infections by Chrysosporium spp. are relatively rare (Suchonwanit et al., 2015).

Arachniotus dankaliensis is rare keratinophilic fungus. It was isolated from the house dust of Aden- Yemen (El-Gindy et al., 2002).

Candida albicans is the most prevalent fungal species of human microbiota. It colonizes asyptomatically the gastrointestinal and genitourinary tracts of healthy individuals. Immunosupressed individuals can be infected with superficial mucosal to hematogenously dissiminated candidiasis (Noble \& Johnson, 2015).

Aspergillus fumigatus followed by A. flavus are the most encountered human pathogens, allergens and mycotoxigenic fungi (Shahhossein et al., 2011 and Hedayati et al., 2007, respectively). 
Rasamsonia byssochlamydoides a thermophilic fungus, newly reported of piles of tea fermentation (Zhang et al., 2016). The fungus has human pathogenesis potentialities.

Exserohilum rostratum was isolated only from animal manure samples (5 isolates and $6.57 \%$ frequency). This fungus is a cross- kingdom jump pathogen of plants and humans. The fungus was newly reported from humans: keratomycosis (Joseph et al., 2012), fungal meningitis (Casadevall and Pirofski, 2013) and invasive rhinusinsitis (Gupta et al., 2014).

Trichophyton terrestre was the only true dermatophyte encountered from our samples. It was reported from mycotic granuloma (Frey et al., 1974). Phoma glomerata was also isolated from our samples. Several cases of human diseases have been observed: mycotic granuloma, otomycosis, rhinitis and allergenic effects (Boerema et al., 1965). A rare case of fungal keratitis was due to $P$. glomerata was also reported (Mc Elnea et al., 2015).

\section{Conclusion}

The presence of keratinophilic and thermophilic fungi in the vicinity of Ayatt draws immediate attention. The pathogenic potentials of these fungi have a high risk for humans and animals. Certain isolates could become useful in managing the environment. Our study will continue for exploitation of some fungi encountered in our soil samples to produce a thermostable keratinase enzyme.

\section{References}

Abdel-Fattah, H.M., Moubasher, A.H. and Maghazy, S.M. (1982) Keratinophilic fungi in Egyptian soils. Mycopathologia, 79, 49-53.

Abdel-Hafez, S. I. I.,Moubasher, A. H. and Barakat, A. (1990) Keratinophilic fungi and other moulds associated with air - dust particles from Egypt. Folia Microbiologica, 35, 311-325.

Al-Humiany, A. A. (2010) Opportunistic pathogenic fungi of the house dust in Turubah kingdom of Saudi Arabia. Aus. J. Basic \& Appl. Sci. 4(2), 122-126.

Benny, G. L. and Benjamin, R. K. (1975) Observations on Thamnidiaceae (Mucorales). New Taxa, new Communities and notes on selected species. Aliso. 8, 301-351.

Bisen, P. and Tiwari, S. (2015) A review on keratiophilic fungi of Madhya Pradesh. $J P B S, \mathbf{1 0}(6), 18-22$.

Boerema, G. H., Dorenboch, M. M. J. and Kesteren, H. A. van (1965) Remarks on species of Phoma referred to Peyronellaea. Persoonia. 5, 201-205.

Bohacz, J. and Kornittowiez-Kowalska, T. (2012) Species diversity of keratinophilic fungi in various soil types. Cent. Euro. J. Biol. 7(2), 259-266. 
Campell, C. K., Johnson, E. M. and Warnock, D. W. (2013) Identification of Pathogenic Fungi. Wiley- Blackwell. UK \& USA.

Casadevall, A. and Pirofski, L. (2013) Exserohilum rostratum fungal meningitis associated with methylpredinsolone infections. Future microbial. 8(2),135-137.

Cooney, D. G. and Emerson, R. (1964) Thermophilic fungi. An account of their Biology, activities and classification. Freeman, San Francisco.

de Hoog, G. S. and Guarro, J. (1995) Atlas of clinical fungi. Centraalbureau voor Schimmel cultures. Baarn. The Netherlands.

Deshmukh, S. K. and Verekar, S. A. (2012) Prevalence of keratinophilic fungi in public park soils of Mumbai, India. Microbiology Research, 3(86), 24-27.

Deshmukh, S. K. and Verekar, S. A. (2014) Incidence of keratinophilic fungi from selected soil of Vidarbha region of Maharashtra state, India. J. of Mycology Article ID 148970, 7 pages.

Domsch, K. H., Gams, W. and Anderson, T. H. (1980) Compendium of Soil Fungi. Acadmic Press, London.

El-Gindy, A. A., Ibrahim, Z. M. and Dughaish, A. H. (2002) Fungi of the house dust in Aden-Yemen. Afr. J. Mycol \& Biotech. 10(1), 49-61.

Ellis, D., Davis, S., Alexion, H., Hankke, R. and Barttey, R. (2007) Description of Medical Fungi. $2^{\text {nd }}$ ed. University of Adelaide. Mycology Unit. Adelaide.

Frey, D., Oldfield, R. J. and Bridger, R. C. (1979) A colour Atlas of Pathogenic Fungi. Wolfe Medical Publication Ltd. London.

Garg, A. P., Gandotra, S., Mukerji, K. G. and Pugh, G. J. F. (1985) Ecology of keratinophilic fungi. Proc. Indian Acad. Sci. (plant sci.). 94(2 \& 3): 149-163.

Gupta, A., Xess, I., Sharma, S. C. and Mallick, S. (2014) Invasive rhinosinusitis by Exserohilum rostratum in an Immunocomptent Child. B. M. J. case report.

Hedayati, M. T., Pasqualotto, A. C., Warn, P. A., Bowyer, P. and Denning, D. W. (2007) Aspergillus flavus: Human pathogen, allergen and mycotoxin producer. Micro. 153, 1677-1692.

Jain, N. and Sharma, M. (2012) A descriptive study of keratinophilic fungal flora of animal and bird habitat, Jaipur, Rajasthan. Afr. J. Microbol. Res. 6(42),6973-6977.

Joseph, N. M., Kumar, M. A., Stephen, S. and Kumar, S. (2012) Keratomycosis caused by Exserohilum rostratum. Ind. J. Pathol. And Microbiol. 55(2), 248-249.

Kacinova, J., Tancinova, D. and Labuda, R. (2013) Keratinophilic fungi in soil stressed by occurrence of animals. J. Microbiol., Biotech. \& Food Sci. 2(1),1436-1446.

Katiyar, S. and Kushwaha, R. K. S. (2002) Invasion and biodegradation of hair by house dust fungi. Inter. J. Biodetr. \& Biodeg. 5(2), 89-93.

Egypt. J. Bot., 56, No. 3 (2016) 
Khan, A. M. and Bhadauria, S. (2015) A review on chemical and molecular characterization of keratinophilic fungi. IJSR. 4(1), 420-423.

Kunert, J. (2000) Physiology of keratinophilic fungi In: Biology of Dermatophytes and the keratinophilic fungi, Kushawaha, R. K. S. and Guarro, J. (Eds). Rev. Iber. Micology. (Spain). 17:77-85.

Latge, J. P. (2003) Aspergillus fumigatus. Asaprophytic pathogenic fungus. Mycologist. 17(2), 56-61.

Maheshwari, R., Bharadwaj, G. and Bhat, M. K. (2000) Thermophilic fungi their physiology and enzymes. Microbiol. Mol. Biot. Rev. 64, 461-488.

Maheshwari, R., Kamalam, P. T. and Balasubramanyam, D. V. C. (1987) The biography of thermophilic fungi. Curr. Sci. 56,151-155.

Mayhraby, T. A., Gherbawy, Y. A. M. H. and Hussein, M. A. (2008) Keratinophilic fungi inhabiting floor dust of student houses at South Valley University in Egypt. Aerobiologia. 24, 99-106.

Mc Elnea, E. M., Farrell, S., Lynch, B., Bishop, K., Mullen, D., Borman, A. and Higgins, G. (2015) Arure case of fungal keratitis: Diagnosis and manegment. JMM Case Reports 1-4.

Morsy, A. A. A. (2007) Mycotic causes of infertility in farm animals. Ph.D. Thesis, Fac Of Veterinary Medicine Assuit University. P 132.

Moubasher, A. H. (1993) Soil fungi in Qatar and otherArab countries. The Scientific and Applied Research Center. University of Qatar. Doha. Qatar.

Mouchaea, J. (1997) Thermophilic fungi: Biodiversity and Taxonomic Status. Crypt. Mycol. 18,19-69.

Mouchaea, J. (2007) Heat tolerant fungi and applied Research: addition to the proviously treated group of stricty thermotolerant species. World J. Microb. Biotech. 23,17751790 .

Nobile, C. J. and Johnson, A. D. (2015) Candida albicans Biofilms and human disease. Ann. Rev. Micro. 69, 71-92.

Rajavanaram, R. K., Bathini, S., Girisham, S. and Redoly, S. M. (2010) Incidence of thermophilic fungi from different substrates In Andhra Pradesh (India). IJPBS. 1(3). www ijpbs.

Salar, R. K. and Aneja, K. R. (2007) Thermophilic fungi: Taxonomy . and biogeography. J. Agric. Technol. 3,77-107.

Sarkar, A. K., Rai, V. and Gupta, A. K. (2014) Incidence of keratinophilic fungi in areas of Rajpur City. Chhattigarh region, India. Afr. J. Micro. Res. 264-269.

Shahhossein, N., Khabiri, A. and Bagheri, F. (2011) The spectrum diseases caused by Aspergillus fumigatus. Review Article, Iran. J. Clin. Infect. Dis. 6(3), 136. 
Sharma, R. and Ghoudhary, N. (2014) A study on role of keratinophilic fungi in nature. A Review. Bifile J. 2(2), 690-701.

Singh, B. and Satyanarayana, T. (2014) Upiquitous occurrence of thermophilic molds in various substrates. In: Fungi from Different substrates (Mishra, J. K., Tewair, J. P.; Deshmukh, S. K. and Vagrolgy, C.). CRC Press pp 201-216.

Singh, I., Mishra, A. and Kushwaha, R. K. S. (2009) Dermatophytes, related kerationphilic and opportunistic Fungi in indoor dust of houses and hospitals. Ind. J. Med. Micro. 27(3), 242-246.

Sirinivasan, B., Kannaian, U. K. and Rang, V. B. P. (2005) Allergenic thermophilic fungi from house dust of Asthmatics. J. of Allergy and Clin. Immunol. 115(2), 26-35.

Sreelatha, B., Shanthi, A. P. and Girisham, S. (2013) Incidence of thermophilic fungi in different drug samples of Warangal district. IJPBS. 3(2), 355-359.

Suchonwanit, P., Chaiyabut, C. and Vachiramon, V. (2015) Primary cutaneous infection following Ear Piercing. Case Rep. Dermatol. 7(2), 136-140.

Van Oorschot, C. A. N. (1980) A revision of Chrysosporium and allied genera. CBS, Baarn, Nether lands. Stud. Mycol. 20, 1-87.

Vanbreseghem, R. (1952) Technique biologique pour I'isolement des dermatophytes du sol (Biological Technique for the Isolation of Dermatophytes from the Soil). Ann. Soc. Belge. Med. Trop. 32,173-178.

Varga, J., Kocsube, S., Toth, B.; Frisvad, J. C., Perrone, G., Susca, A., Meijer, M. and Samson, R. A. (2007) Aspergillus brasiliensis sp. nov., a biseriate Aspergillus species. Int. J. Syst. \& Evol. Micro. 57, 1925-1932.

Yang, C., Pakpour, S., Klironomos, J. and Li, De-Wie (2016) Micro fungi in indoor environment. In: Biology of Micro Fungi, Li, De-Wie (Ed.), Springer. Pp 373-412.

Zhang, W., Yang, R., Fang, W., Yan, L., Lu, J., Sheng, J. and Lv, J. (2016) Characterization of thermophilic fungal community associated with pile fermentation of Pu-Erh tea. Int. J. Food Microbiol. 227-229. 


\section{الفطريات المحلة للكراتين و المحبة للحرارة المعزولة من عينات

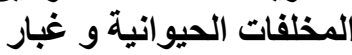

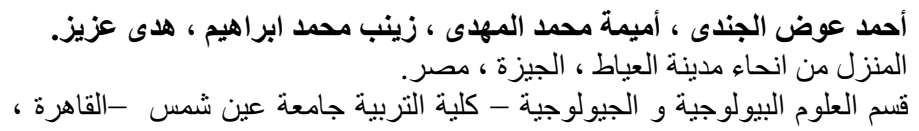
columnaris, Rasamsonia byssochlamydoides, Chrysosporium zonatum $(6.66 \%)$ 